\title{
Culture-based study on the
} increasing doses of streptomycin

\author{
Ganesh-Kumar Selvaraj ${ }^{1}$, Zhe Tian ${ }^{1,2}$, Hong Zhang ${ }^{1}$, Mohanapriya Jayaraman ${ }^{1}$, Min Yang ${ }^{1,2}$ and Yu Zhang ${ }^{1,2^{*}}$
}

\begin{abstract}
The effects of streptomycin (STM) on the development of antibiotic resistance in an aerobic-biofilm reactor was explored by stepwise increases in STM doses $\left(0-50 \mathrm{mg} \mathrm{L}^{-1}\right)$, over a period of 618 days. Totally 191 bacterial isolates affiliated with 90 different species were harvested from the reactor exposed to six STM exposures. Gammaproteobacteria (20-31.8\%), Bacilli (20-35.7\%), Betaproteobacteria (4.5-21\%) and Actinobacteria (0-18.2\%) were dominant, and their diversity was not affected over the whole period. Thirteen dominant isolates from each STM exposures (78 isolates) were applied to determine their resistance prevalence against eight classes of antibiotics. Increased STM resistance (53.8-69.2\%) and multi-drug resistance (MDR) (46.2-61.5\%) were observed in the STM exposures (0.1-50 $\left.\mathrm{mg} \mathrm{L}^{-1}\right)$, compared to exposure without STM (15.3 and 0\%, respectively). Based on their variable minimum inhibitory concentration results, 40 differentiated isolates from various STM exposures were selected to check the prevalence of nine aminoglycoside resistance genes (aac(3)-II, aacA4, aadA, aadB, aadE, aphA1, aphA2, strA and strB) and two class I integron genes ( $3^{\prime}-C S$ and Int). STM resistance genes (aadA, strA and strB), a non-STM resistance gene ( $a a c A 4)$ and integron genes ( $3^{\prime}-C S$ and Int1) were distributed widely in all STM exposures, compared to the exposure without STM. This new culture-based stepwise increasing antibiotic approach reveals that biological systems treating wastewater with lower STM dose $\left(0.1 \mathrm{mg} \mathrm{L}^{-1}\right)$ could lead to notably increased levels of STM resistance, MDR, and resistant gene determinants, which were sustainable even under higher STM doses $\left(>25 \mathrm{mg} \mathrm{L}^{-1}\right)$.
\end{abstract}

Keywords: Streptomycin (STM), Multi drug resistance (MDR), Antibiotic resistance genes (ARGs), Stepwise increasing STM doses

\section{Introduction}

The broad use of antibiotics in the fields of medical therapy, animal husbandry, and plant disease control during the past 65 years has resulted in the rapid growth and global prevalence of antibiotic resistance. In recent years, municipal wastewater treatment plants (WWTPs) have been considered as the main source for the development of antibiotic resistant bacteria (ARB) and

\footnotetext{
*Correspondence: zhangyu@rcees.ac.cn

${ }^{1}$ State Key Laboratory of Environmental Aquatic Chemistry, Research Center for Eco-Environmental Sciences, Chinese Academy of Sciences, Beijing 100085, China

Full list of author information is available at the end of the article
}

antibiotic resistance genes (ARGs), as they consist of a mixed bacterial community maintained by rich nutrient environments, and experience repeated contamination by resistant bacteria and exposure to various antibiotics (Gallert et al. 2005; Novo and Manaia 2010; Rizzo et al. 2013; Michael et al. 2013; Guo et al. 2017; Mao et al. 2015; Rodriguez-Mozaz et al. 2015; Aubertheau et al. 2017). In comparison with municipal WWTPs, however, antibiotic production WWTPs could become a hotspot for the development of antibiotic resistance due to the presence of much higher concentrations of antibiotics (Pruden et al. 2013; Ashbolt et al. 2013). It is important, therefore, to know the threshold concentration of antibiotics that leads to antibiotic resistance. 
Our previous study showed that the presence of high concentrations of antibiotics (oxytetracycline, $>19.5 \mathrm{mg} \mathrm{L}^{-1}$ ) in a biological WWTP could lead to the occurrence of tetracycline resistance and MDR in treated wastewater and downstream rivers (Li et al. 2010). Similar results have also been observed in antibiotic production WWTPs accepting penicillin and spiramycin production wastewater (Li et al. 2009, 2011; Liu et al. 2014). However, most of these studies have been derived from investigative results of full-scale real WWTPs, and do not reveal the influence of antibiotic concentrations. Recently some effort has been made to investigate the influence of minimum antibiotic concentrations on the transfer of MDR under controlled experimental conditions. Under such studies, concentrations of tetracycline and sulfamethoxazole, as low as $10-100 \mu \mathrm{g} \mathrm{L}^{-1}$ were found to promote MDR through the horizontal dissemination of mobile resistance elements (Jutkina et al. 2016; Kim et al. 2014). However, pure cultures and overnight culture times have often been adopted for these experiments, which may not be able to reveal the impact of antibiotic concentrations on the wastewater treatment bacteria.

In the current new approach, a biofilm-type wastewater treatment reactor was constructed to treat synthetic wastewater under stepwise increasing doses of STM (0, $0.1,1,5,25$ and $50 \mathrm{mg} \mathrm{L}^{-1}$ ) over a period of 618 days, with a control system (no antibiotics) operated in parallel. Streptomycin is one of the first broad-spectrum antibiotics to be utilized for the control of infectious human and plant diseases. Although STM resistance mechanisms have been proposed in many clinical bacteria, plant and animal pathogens (De Leon Door et al. 2013; Sundin et al. 1995; Sundin 2002; Um et al. 2016), the resistance spectra in wastewater communities are still poorly understood. In additions, the culture-based wastewater bacterial responses against stepwise increasing doses of STM have not been studied. In this study, wastewater bacterial strains were isolated from six different STM exposures, and the impacts of antibiotic concentrations on wastewater bacterial diversity and the characteristics of antibiotic resistance were assessed using bacterial enrichment method, sequencing and, MIC assay. The presence and distribution of 11 antibiotic genetic determinants from individual wastewater bacterial isolates were determined by the conventional polymerase chain reaction (PCR). The results of this new culture-based stepwise increasing STM approach will enable us to better understand the risks accompanying antibiotic wastewater treatment.

\section{Materials and methods}

\section{Sampling source}

Two lab scale wastewater reactors $(15 \times 10 \times 29.5 \mathrm{~cm}$ in size) were constructed with an effective volume of
$2 \mathrm{~L}$, and were each filled with 18 fiber balls as bio-carriers (Additional file 1: Fig. S1). Activated sludge from a municipal wastewater treatment plant in Beijing was used as the initial seeding inoculum. Glucose, tryptone, starch and sodium-carboxymethyl cellulose were used as the mixed carbon sources for the synthetic wastewater (Additional file 1: Table S1). Wastewater was fed into the reactors with a hydraulic retention time (HRT) of $24 \mathrm{~h}$ at room temperature $\left(20 \pm 5{ }^{\circ} \mathrm{C}\right)$. After the start-up period (1 month), one reactor was used to treat wastewater containing STM [streptomycin sulfate (95\%), TCI, Shanghai, China] and the other was used as the control to treat wastewater without STM. The dosage of STM was increased stepwise in six exposures $(0,0.1,1,5,25$ and $50 \mathrm{mg} \mathrm{L}^{-1}$ ), with each exposures maintained for at least 14 weeks. The stability of wastewater treatment performance was confirmed by monitoring the effluent ammonium concentration. Increases in the STM dose were implemented only when the reactor had operated at an effluent ammonium concentration below $1 \mathrm{mg} \mathrm{L}^{-1}$ for over 1 month. The whole experimental period spanned 618 days including the start-up period. At the end of each STM exposure, two plastic balls were taken out of the reactor for biological analysis and the same number of fresh balls was put into the reactors. Each ball was shaken with $50 \mathrm{~mL}$ of phosphate buffer saline (PBS) and the solution was centrifuged at 10,000 rpm for $10 \mathrm{~min}$ at $4{ }^{\circ} \mathrm{C}$. The same supernatant was used to wash the balls repeatedly until they returned to their original color. The processed sludge samples were stored at $-80{ }^{\circ} \mathrm{C}$ as a $30 \%$ glycerol stock solution for future use.

\section{Bacterial enrichment and purification}

Ten-fold serial dilutions were performed for the processed sludge samples collected from all six exposures of the STM reactor and control reactor. The frozen sludge samples were firstly thawed gradually and homogenized by an ultra-Turrax disperser (IKA, T10 basic S25-unit). Triplicate non-selective media including TSA and R2A (Difco, France), were simultaneously prepared and inoculated by $0.1 \mathrm{ml}$ aliquots of diluted sludge samples. Inoculated plates (As one, Shanghai, China) were incubated at $30{ }^{\circ} \mathrm{C}$ for $12-48 \mathrm{~h}$. Bacteria with different morphologies were re-streaked at least three times on fresh corresponding media to obtain pure cultures. All cultivable bacteria were thoroughly screened and purified from all the STM exposures in biological reactor. Colony forming units (CFUs) of the various sludge samples were simultaneously determined on the TSA medium and microbial purity was checked by the Gram's stain method. Purified bacteria from all STM exposures were stored as 30\% glycerol stock solutions in the corresponding media at $-80^{\circ} \mathrm{C}$ for future analysis. 


\section{S rRNA gene analysis}

To identify the bacterial isolates from all six STM exposures, genomic DNA was extracted from all purified bacteria and the 16S rRNA genes were amplified using universal primers (27F and 1492R). Bacterial genomic DNA was harvested using a TIANamp bacteria DNA kit, and the DNA concentration was determined using a Nanodrop 1000 spectrophotometer (Nanodrop, USA). Genomic DNA (50 ng) was used as the template DNA for the PCR mixture. The PCR mixture $(25 \mu \mathrm{L})$ contained $1 \times$ PCR buffer $\left(\mathrm{MgCl}_{2}{ }^{+}\right), 2.5 \mathrm{mM}$ dNTPs mix, $0.5 \mu \mathrm{M}$ of each primer, and $1 \mathrm{U}$ of Taq DNA polymerase (Takara, Bio Inc, Shiga, Japan). The $16 \mathrm{~S}$ rRNA-PCR conditions were as follows: initial denaturation at $94{ }^{\circ} \mathrm{C}$ for $10 \mathrm{~min}$, followed by 30 cycles of denaturation at $94^{\circ} \mathrm{C}$ for $1 \mathrm{~min}$, annealing at $52^{\circ} \mathrm{C}$ for $1 \mathrm{~min}$, extension at $72{ }^{\circ} \mathrm{C}$ for $2 \mathrm{~min}$, and a final extension at $72{ }^{\circ} \mathrm{C}$ for $10 \mathrm{~min}$. After the PCR, the amplified PCR products were resolved on $1 \%$ agarose (Biowest, Hong Kong) gel.

\section{Sequencing and phylogenetic analysis}

The purified PCR products were sequenced using an ABI3730 automated sequencer (Invitrogen, Shanghai, China). Bacterial 16S rRNA gene sequences were analyzed manually using Bioedit software. Sequenced DNA was compared using the Ribosomal Database Project (RDP) and GenBank-National Center for Biotechnology Information (NCBI) database, and sequence similarities above $99 \%$ were considered identified for species the level and above $98 \%$ for the genus level. The MEGA6 (Tamura et al. 2013) and Clustal W (Larkin et al. 2007) software were used to draw dendrograms of 90 different isolated bacterial strains. Bacterial phylogeny was tested using neighbor-joining and statistical analysis was done by the bootstrap method. Bootstrap analysis was used to determine the confidence values of phylogenetic tree nodes using 1000 replicates (Felsenstein 1985). The partial 16S rRNA gene sequences of isolates were deposited in NCBI, GenBank under various Accession Numbers (KY087979, KY087986-87, KY087989-90, KY39299915, KY393017-36, KY393045-54, and KY393058-95).

\section{Minimum inhibitory concentration (MIC) assay}

A total of 40 different bacterial strains (78 bacterial isolates, 13 from each STM exposure) were selected for testing of antibiotic resistance prevalence based on their dominance in all six STM exposures at the genus level. Determinations of MICs described in this protocol were in accordance with the recommendations given by the Clinical and Laboratory Standards Institute (CLSI 2016). Among the nine antibiotics (including eight different classes of antibiotics), the Etest gradient method was applied for azithromycin (AZ), ceftazidime (TZ), enrofloxacin (EF), sulfamethoxazole (SX), tetracycline (TC), tobramycin (TM), tigecycline (TGC), and ertapenem (ETP) (Additional file 1: Table S4). The Etest strips were purchased from Biomerieux (France). Micro-dilution (96-well-plate method) was applied only for STM, since Etest strip for this antibiotic was not commercially available. Overnight Mueller Hinton (MH) broth (Oxoid, England) culture was prepared from a single colony and its turbidity was adjusted in accordance with the 0.5 McFarland standard solutions. This diluted broth culture was used as the inoculum for both tests. The bacterial lawn was prepared on the MH plates (duplicates) using a cotton swab and the corresponding Etest strip was applied on the inoculated MH agar surface. Finally, airdried inoculated plates were incubated at $30{ }^{\circ} \mathrm{C}$ for $24 \mathrm{~h}$. For the 96-well-plates, the same diluted broth culture $(75 \mu \mathrm{L})$ was loaded in each well of the micro-titer plates (in triplicate) containing STM solutions $(75 \mu \mathrm{L})$ and incubated at $30{ }^{\circ} \mathrm{C}$ for $24 \mathrm{~h}$ (Andrews 2001). Since no elaborated CLSI guidelines are available for the environmental non-pathogenic bacteria, the antibiotic break point limits for MIC interpretation are scarce. Thus, the MIC patterns were grouped as sensitive $\left(0.016-12 \mu \mathrm{g} \mathrm{mL} \mathrm{m}^{-1}\right)$, resistant $\left(13-64 \mu \mathrm{g} \mathrm{mL}^{-1}\right.$ ) and highly resistant (64 to $>256 \mu \mathrm{g} \mathrm{mL}^{-1}$ ) (Lundstrom et al. 2016; Popowska et al. 2012). However a cut-off value for STM $\left(>8 \mu \mathrm{g} \mathrm{mL}{ }^{-1}\right)$ among E. coli was considered for STM resistance in this study (Sunde and Norstrom 2005).

\section{Screening of antibiotic genetic determinants}

The presences of nine aminoglycoside resistance genes (aac(3)-II, aacA4, aadA, aadB, aadE, aphA1, aphA2, strA and $s t r B)$, one clinical class I integron gene $\left(3^{\prime}-C S\right)$ and one class I integrase gene (IntI) were screened from 11 different bacterial strains (including 40 isolates from the six STM exposures), which exhibited variable MIC values with the increase in STM doses. Details of the specific primers used in this study are listed in Additional file 1: Table S6. The bacterial DNA template ( $50 \mathrm{ng})$ was used and the PCR conditions were applied as described above ("16S rRNA gene analysis" section). However, the annealing temperature varied based on the specific primers used. After the PCR reactions, specific gene products were analyzed on $1.2 \%$ agarose gel stained with ethidium bromide. The sequenced resistance genes were checked by BLASTN in, GenBank, NCBI.

\section{Results}

\section{Culture-based bacterial diversity}

A total of 191 purified bacterial isolates including 56, 28, $26,29,26$ and 26 isolates were harvested from the $0,0.1,1$, 5, 25 and $50 \mathrm{mg} \mathrm{L}^{-1}$ STM exposures, respectively (Additional file 1: Table S2). A total of 90 different bacterial 
species including 7 classes, 44 genera and 25 families, were harvested from all six exposures of the STM reactor (Table 1), with the phylogenetic relationships of the total bacterial species illustrated in Fig. 1. Gammaproteobacteria (20-31.8\%), Bacilli (20-35.7\%), Betaproteobacteria (4.5-2\%) and Actinobacteria (0-18.2\%) were dominant in all six STM exposures $\left(0-50 \mathrm{mg} \mathrm{L}^{-1}\right)$ (Fig. 2). The remaining distributed bacterial classes were Alphaproteobacteria (0-13.3\%), Flavobacteria (0-18.2\%) and Sphingobacteria (0-5.2\%). Overall, bacterial genera such as Bacillus, Pseudomonas, Aeromonas, Microbacterium and Acinetobacter were dominant, and bacterial species such as Aeromonas veronii, Bacillus anthracis, Chryseobacterium lactis, Comamonas testosteroni, Lactococcus chungangnensis and Microbacterium maritypicum were predominantly present in almost all STM exposures. Similar bacterial diversity was observed in the control reactor (Additional file 1: Table S3) without STM $\left(0 \mathrm{mg} \mathrm{L}^{-1}\right)$. Therefore those stains from the control system were not used for further analysis (data not included). Principal coordinates analysis (PCoA) showed that bacterial community in the STM exposures such as 5,25 and $50 \mathrm{mg} \mathrm{L}^{-1}$ were clustered near by locations and its biodiversity was differed significantly with 0 and $0.1 \mathrm{mg} \mathrm{L}^{-1}$ STM exposures (Additional file 1: Fig. S2). From both the control and STM reactor, the approximate CFU in the TSA media ranged from $(3.2 \pm 1.8) \times 10^{4}$ to $(5.4 \pm 1.4) \times 10^{4}$ (average of triplicate plates).

\section{Determination of MICs}

From the MIC results, $53.8-69.2 \%$ of STM resistance was observed in the presence of STM doses of $0.1-50 \mathrm{mg} \mathrm{L}^{-1}$ (Fig. 3a), whereas only $15.4 \%$ of STM resistance was observed in the exposure without STM $\left(0 \mathrm{mg} \mathrm{L}^{-1}\right)$. Bacterial strains such as Aeromonas allosaccharophila, Aeromonas veronii, Chryseobacterium lactis, Comamonas testosteroni, Pseudoxanthomonas mexicana, Acinetobacter sp., Microbacterium maritypicum, Microbacterium lacticum, Raoultella terrigena and Sphingopyxis chilensis exhibited highly resistance to streptomycin (> $1024 \mu \mathrm{g} \mathrm{mL}^{-1}$ ) in the corresponding STM exposures (Additional file 1: Table S5). In other hand, Bacillus amyloliquefaciens, Bacillus anthracis, Bacillus cereus, Bacillus stratosphericus, Brevundimonas bullata, Trichococcus flocculiformis and Leucobacter sp. showed least resistance to the STM $\left(<8 \mu \mathrm{g} \mathrm{mL}^{-1}\right)$.

The capability for MDR was $46.2-61.53 \%$ among the isolates harvested from the 0.1 to $50 \mathrm{mg} \mathrm{L}^{-1}$ STM exposures, whereas there was no capability of MDR observed in the exposure without STM (Fig. 3b). Bacterial isolates including Aeromonas allosaccharophila, Chryseobacterium lactis, Comamonas testosteroni and Microbacterium maritypicum exhibited resistance to at least four different antibiotics, simultaneously. The bacterial isolates from various STM exposures exhibited co-resistance to azithromycin, ceftazidime, sulfamethoxazole, tobramycin and tetracycline with a ratio of $7.7-38.4 \%$, whereas no or low co-resistance $(0-7.7 \%)$ was observed for the antibiotics including enrofloxacin, tigecycline or ertapenem (Table 2; Additional file 1: Fig. S3).

\section{Prevalence of antibiotic resistance genes and class I integron genes}

Amino glycoside resistance genes $\operatorname{str} A, \operatorname{str} B, \operatorname{aad} A$ and aacA4 (83.3-100\%), and integron genes IntI and $3^{\prime}-C S$ (97.5-100\%) were widely observed among the strains harvested from the 0.1 to $50 \mathrm{mg} \mathrm{L}^{-1}$ STM exposures (Table 3; Additional file 1: Table S7), whereas STM resistance genes $\operatorname{str} A$ and $\operatorname{str} B(50.0 \%)$ and integron genes IntI (30\%) and $3^{\prime}-C S(70 \%)$ were also observed in the exposure without STM. In addition, other amino glycoside genes including aac(3)-II, aphA1, aphA2, aadE and $a a d B$, were not notably distributed $(0-17.5 \%)$ among the various STM exposures. In particular, the aadE gene (confers resistance to STM and spectinomycin) was observed only in Lactococcus chungangensis $\left(1-50 \mathrm{mg} \mathrm{L}^{-1}\right)$, whereas none of the STM resistant strains contained the aac(3)-II gene (confers resistance to gentamycin, tobramycin and kanamycin). In this study, Lactococcus chungangensis and Stenotrophomonas acidaminiphila exhibited the maximum number of amino glycoside resistance genes (six), whereas Paracoccus yeei, Lactococcus raffinolactis, Pseudoxanthomonas mexicana and Chryseobacterium lactis contained five amino glycoside resistance genes (Additional file 1: Fig. S4) and Aeromonas veronii and Comamonas testosteroni contained three amino glycoside resistance genes.

\section{Discussion}

Although culture-independent approaches (metagenomic) are widely used in recent times, bacterial antibiotic prevalence and resistant patterns are more accurate and evident only by the culture-dependent approaches (Czekalski et al. 2012). In the present culture-based longterm study, bacterial classes including Gammaproteobacteria, Bacilli and Betaproteobacteria were dominant in the reactor regardless of the presence or absence of STM (Fig. 2). In addition, major genera included Aeromonas, Pseudomonas, Comamonas, and Bacillus was dominant in all six STM exposures (Table 1; Additional file 1: Table S2). In our previous culture-independent study, bacterial classes including Gammaproteobacteria, Betaproteobacteria and Bacteroidetes dominated in the aerobic-biofilm reactors mainly receiving the wastewater containing STM, whereas the major genera included Dokdonella, Pseudomonas, Desulfocapsa and Geobacter (Deng et al. 
Table 1 Phylogenetic affiliation of bacterial isolates harvested from stepwise increasing doses of STM treating aerobicbiofilm reactor

\begin{tabular}{|c|c|c|c|}
\hline Bacterial classes & Bacterial families & Bacterial name & Distribution in STM stages $\left(\mathrm{mg} \mathrm{L}^{-1}\right)$ \\
\hline \multirow[t]{13}{*}{ Actinobacteria } & \multirow[t]{6}{*}{ Microbacteriaceae } & Agromyces mediolanus & 50 \\
\hline & & Leucobactersp. & 0 \\
\hline & & Microbacterium arabino & 0,1 \\
\hline & & Microbacterium lacticum & $0.1,50$ \\
\hline & & Microbacterium lacus & 0 \\
\hline & & Microbacterium maritypicum & $0.1,5,25,50$ \\
\hline & \multirow[t]{5}{*}{ Micrococcaceae } & Arthrobacter nicotinovorans & 50 \\
\hline & & Kocuria rhizophila & $0,0.1$ \\
\hline & & Micrococcus aloeverae & 0,1 \\
\hline & & Micrococcus yunnanensis & 0 \\
\hline & & Rothia terrae & 5 \\
\hline & \multirow[t]{2}{*}{ Nocardiaceae } & Rhodococcus jialingiae & 5 \\
\hline & & Rhodococcus yunnanensis & 0 \\
\hline \multirow[t]{7}{*}{ Alphaproteobacteria } & \multirow[t]{2}{*}{ Caulobacteraceae } & Brevundimonas bullata & 50 \\
\hline & & Brevundimonas terrae & 0 \\
\hline & Rhizobiaceae & Shinella zoogloeoides & 0 \\
\hline & Rhodobacteraceae & Paracoccus yeei & $0,0.1$ \\
\hline & \multirow[t]{3}{*}{ Sphingomonadaceae } & Sphingobium xenophagum & 0 \\
\hline & & Sphingopyxis chilensis & 1,25 \\
\hline & & Sphingopyxis terrae & 50 \\
\hline \multirow[t]{17}{*}{ Bacilli } & \multirow[t]{11}{*}{ Bacillaceae } & Bacillus amyloliquefaciens & 0,5 \\
\hline & & Bacillus anthracis & $0,0.1,1,5,25,50$ \\
\hline & & Bacillus aryabhattai & $0,0.1$ \\
\hline & & Bacillus cereus & $0.1,1$ \\
\hline & & Bacillus flexus & 0.1 \\
\hline & & Bacillus safensis & $0,0.1$ \\
\hline & & Bacillus simplex & 5 \\
\hline & & Bacillus stratosphericus & 5,25 \\
\hline & & Bacillus thioparans & 0 \\
\hline & & Bacillus toyonensis & 0 \\
\hline & & Lysinibacillus fusiformis & 0 \\
\hline & \multirow[t]{2}{*}{ Carnobacteriaceae } & Trichococcus flocculiformis & 0 \\
\hline & & Trichococcus pasteurii & 0 \\
\hline & \multirow[t]{3}{*}{ Staphylococcaceae } & Staphylococcus capitis & 0 \\
\hline & & Staphylococcus epidermidis & 1 \\
\hline & & Staphylococcus warneri & 0 \\
\hline & Streptococcaceae & Streptococcus parauberis & 0 \\
\hline \multirow[t]{11}{*}{ Betaproteobacteria } & Burkholderiaceae & Chitinimonas viridis & 1,50 \\
\hline & \multirow[t]{8}{*}{ Comamonadaceae } & Acidovorax temperans & 0 \\
\hline & & Comamonas sp. & 1 \\
\hline & & Comamonas testosteroni & $0,0.1,1,5$ \\
\hline & & Delftia acidovorans & 5,50 \\
\hline & & Delftia sp. & 0 \\
\hline & & Delftia tsuruhatensis & 1 \\
\hline & & Hydrogenophaga pseudoflava & 5 \\
\hline & & Hydrogenophaga taeniospiralis & 25 \\
\hline & \multirow[t]{2}{*}{ Oxalobacteraceae } & Massilia timonae & 50 \\
\hline & & Massilia varians & 25,50 \\
\hline
\end{tabular}


Table 1 continued

\begin{tabular}{|c|c|c|c|}
\hline Bacterial classes & Bacterial families & Bacterial name & Distribution in STM stages $\left(\mathrm{mg} \mathrm{L}^{-1}\right)$ \\
\hline & Rhodocyclaceae & Dechloromonas sp. & 25 \\
\hline & & Zoogloea caeni & 5 \\
\hline & Streptococcaceae & Lactococcus chungangensis & $0,0.1,1,5,25,50$ \\
\hline & & Lactococcus raffinolactis & 0,1 \\
\hline \multirow[t]{9}{*}{ Flavobacteria } & Cytophagaceae & Runella zeae & 0 \\
\hline & Flavobacteriaceae & Chryseobacterium sp. & $0.1,1$ \\
\hline & & Chryseobacterium lactis & $0,0.1,1,5,25$ \\
\hline & & Chryseobacterium rhizoplanae & 0 \\
\hline & & Cloacibacterium normanense & 0 \\
\hline & & Cloacibacterium rupense & 0 \\
\hline & & Flavobacterium hibernum & $0.1,5$ \\
\hline & & Flavobacterium sasangense & 0.1 \\
\hline & & Wautersiella falsenii & 0 \\
\hline \multirow[t]{27}{*}{ Gammaproteobacteria } & Aeromonadaceae & Aeromonas caviae & 5 \\
\hline & & Aeromonas allosaccharophila & $0,25,50$ \\
\hline & & Aeromonas media & 0 \\
\hline & & Aeromonas salmonicida & 5 \\
\hline & & Aeromonas veronii & $0,0.1,25$ \\
\hline & Enterobacteriaceae & Lelliottia amnigena & 0 \\
\hline & & Raoultella ornithinolytica & 0.1 \\
\hline & & Raoultella terrigena & $1,25,50$ \\
\hline & Moraxellaceae & Acinetobacter gyllenbergii & 0.1 \\
\hline & & Acinetobacter johnsonii & 0.1 \\
\hline & & Acinetobacter seohaensis & 0 \\
\hline & & Acinetobacter sp. & $1,5,50$ \\
\hline & Pseudomonadaceae & Pseudomonas azotoformans & 5 \\
\hline & & Pseudomonas japonica & 0 \\
\hline & & Pseudomonas koreensis & 1 \\
\hline & & Pseudomonas mendocina & 25 \\
\hline & & Pseudomonas monteilii & 5 \\
\hline & & Pseudomonas putida & 1 \\
\hline & Shewanellaceae & Shewanella putrefaciens & 1 \\
\hline & Xanthomonadaceae & Lysobacter brunescens & 0 \\
\hline & & Lysobacter sp. & 0 \\
\hline & & Pseudoxanthomonas japonensis & 5,50 \\
\hline & & Pseudoxanthomonas mexicana & $0,5,25,50$ \\
\hline & & Pseudoxanthomonas sp. & 50 \\
\hline & & Stenotrophomonas sp. & 0.1 \\
\hline & & Stenotrophomonas acidaminiphila & $0,0.1$ \\
\hline & & Tahibacter aquaticus & $5,25,50$ \\
\hline Sphingobacteria & Cytophagaceae & Dyadobacter sp. & 1 \\
\hline
\end{tabular}

2012). There are three possible reasons for this difference in bacterial compositions. The mixture of carbon sources used in the study, including glucose, tryptone, starch and sodium-carboxymethyl cellulose might have favored the different composition of genera. The culturebased approach might also produce favorable conditions for some bacterial genera in the WWTPs (Bramucci et al. 2003). On the other hand, anaerobic genera including Desulfocapsa and Geobacter might have come from the two anaerobic reactors used in the previous study, which received beta-lactam antibiotics at a minimal level $\left(1.7-2.1 \mu \mathrm{g} \mathrm{L}^{-1}\right)$. In this study, major bacterial genera and their populations were not disturbed even at the higher STM dose $\left(25\right.$ and $\left.50 \mathrm{mg} \mathrm{L}^{-1}\right)$. It reveals that increasing 


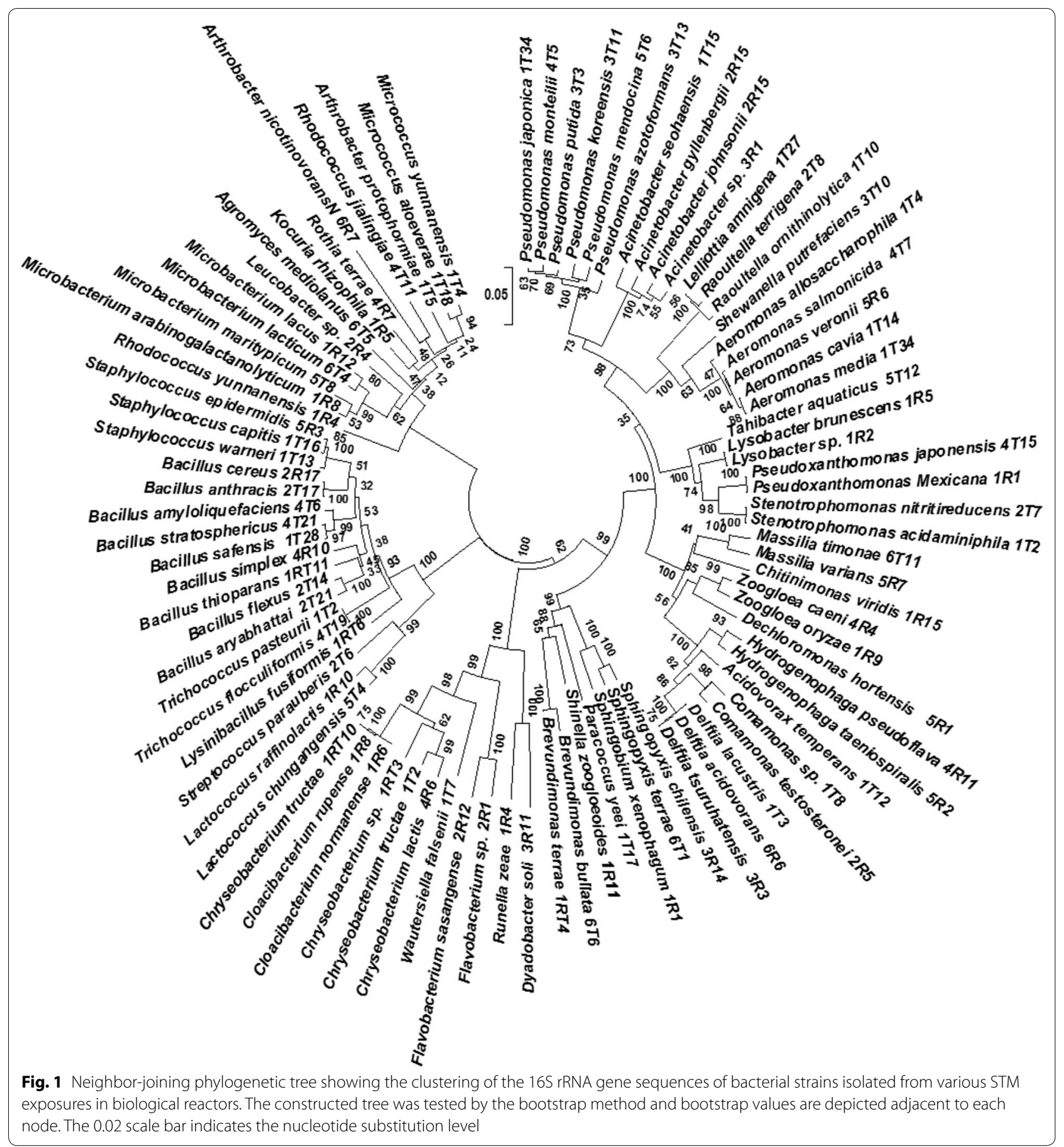

STM doses did not affect the major bacterial diversity of the wastewater treatment system. Therefore, it is possible that they maintained their presence in the reactor by adopting antibiotic resistance in stepwise increasing doses of STM.

In the present study, bacterial isolates from the STM exposure reactor exhibited multi-resistance to other unrelated classes of antibiotics including macrolides, $\beta$-lactams, sulfonamides and tetracycline (Table 2; Additional file 1: Fig. S3). In our previous studies, similar multi-resistance observations were also described in wastewater systems accepting penicillin and oxytetracycline (Li et al. 2009, 2010). These related effects have also been observed in other sources such as clinical 


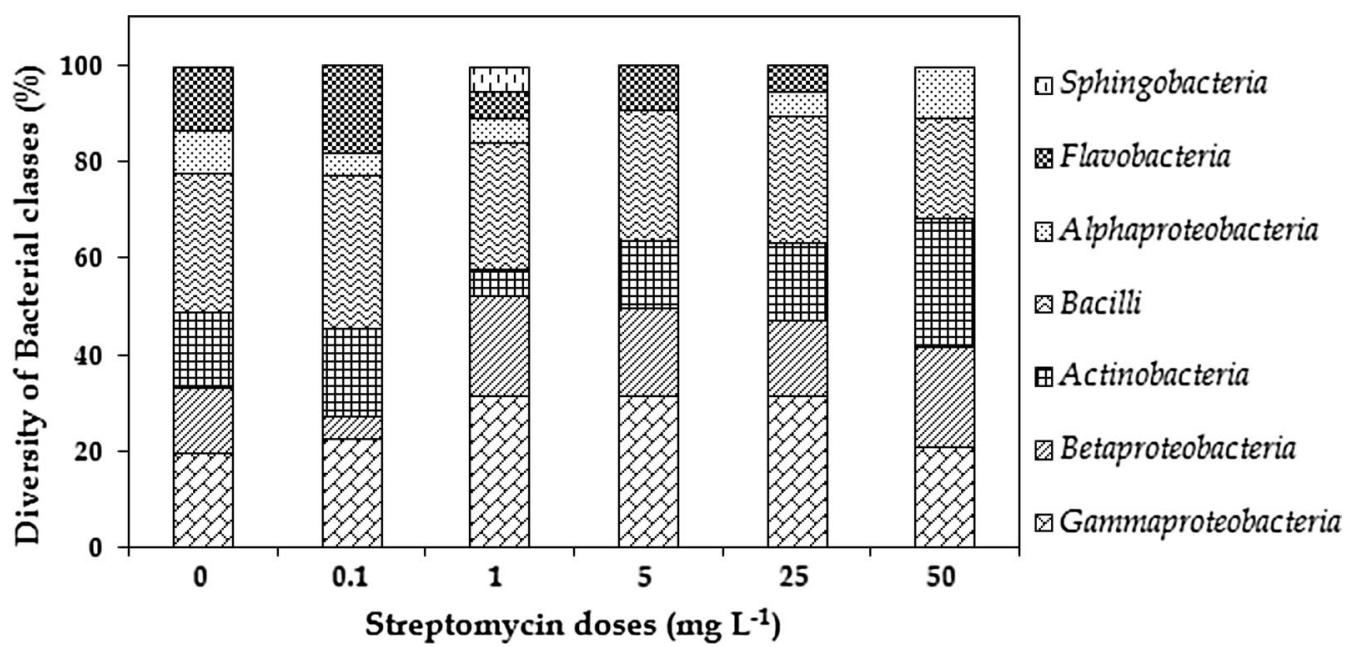

Fig. 2 Distribution of bacterial classes harvested from the long-term wastewater reactor treated with stepwise-increasing doses of streptomycin
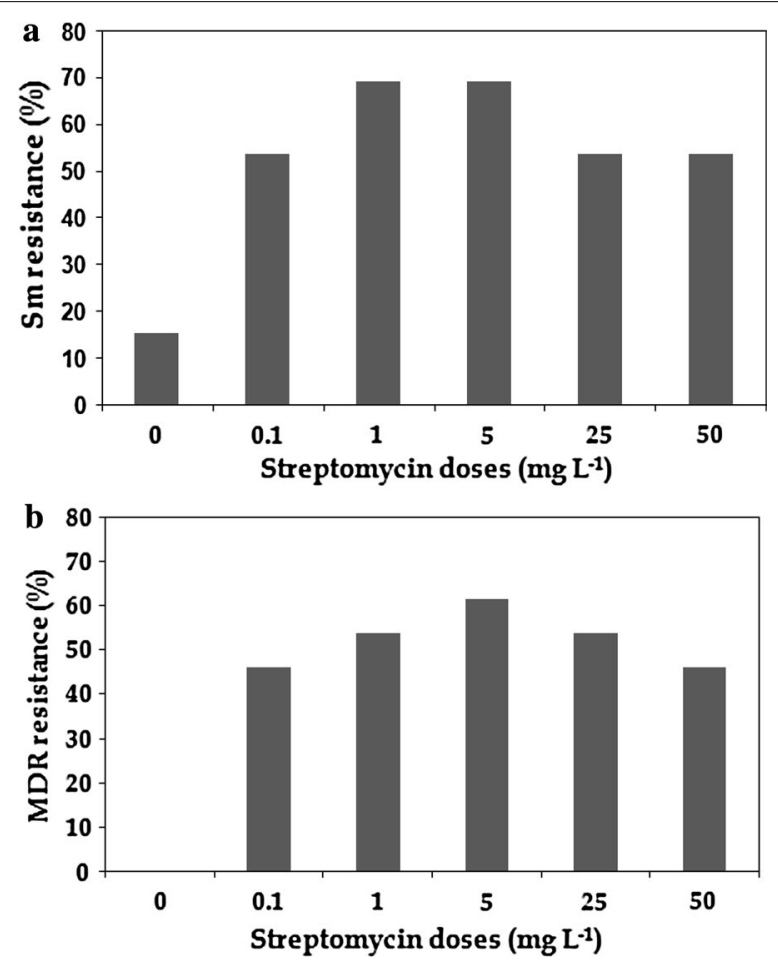

Fig. $3 \mathrm{MIC}$ assay showing the prevalence of bacterial streptomycin resistance $(\mathbf{a})$ and MDR $(\mathbf{b})$ in the various streptomycin exposures. A total of 78 dominant bacterial isolates (13 isolates from each exposure) and nine antibiotics were used for the MIC assay. The number of resistant strains among the total strains was taken for the calculation of resistance prevalence (\%)

pathogens, chicken farms and aquatic systems (Tacao et al. 2014; Wong et al. 2014; Levy et al. 1976). According to previous other study on the overnight culture-based activated sludge samples exposed to minimal doses of
STM $\left(>0.1 \mathrm{mg} \mathrm{L}^{-1}\right)$ showed decreased bacterial multiresistance by controlling the transfer of mobile genetic elements (Kim et al. 2014). In the current long-term study, minimum doses of STM $\left(>0.1 \mathrm{mg} \mathrm{L}^{-1}\right)$ exhibited increased multi resistance (Fig. 3), whereas the higher doses of STM (> $25 \mathrm{mg} \mathrm{L}^{-1}$ ) exhibited stable multiresistance. Similarly, on other hand, STM resistance also increased at minimum doses of STM $\left(>0.1 \mathrm{mg} \mathrm{L}^{-1}\right)$ and was maintained at the higher doses of STM $\left(>25 \mathrm{mg} \mathrm{L}^{-1}\right)$, whereas negligible STM resistance and multi-resistance were noted under no STM dose $\left(0 \mathrm{mg} \mathrm{L}^{-1}\right)$. We considered, therefore, that minimum doses of long-term exposure STM might induce significant MDR and STM resistance simultaneously, and the resistance could be able to persist even under higher doses of STM among the wastewater bacterial community.

It is interesting that the responses of every culturable wastewater bacterial strain to the stepwise increasing doses of STM were variable and unambiguous. Chryseobacterium lactis and Comamonas testosteroni naturally $\left(0 \mathrm{mg} \mathrm{L}^{-1}\right)$ possessed STM resistance genes (strA and $s t r B)$ and a class I integron gene $\left(3^{\prime}-C S\right)$ (Table 3; Additional file 1: Table S7), and showed high MIC values against STM $\left(>256 \mu \mathrm{g} \mathrm{mL}^{-1}\right)$ in the exposure without STM (Additional file 1: Table S5). Meanwhile, Lactococcus chungangensis, Pseudoxanthomonas mexicana and Lactococcus raffinolactis also naturally $\left(0 \mathrm{mg} \mathrm{L}^{-1}\right)$ possessed STM resistance genes $(\operatorname{str} A$ and $\operatorname{str} B)$ and an integron gene $\left(3^{\prime}-C S\right)$, but showed low MIC values against STM $\left(<6 \mu \mathrm{g} \mathrm{mL}^{-1}\right)$ under the exposure without STM. Subsequently, however the above isolates obtained STM resistance under the lower doses of STM $(0.1,1$, or $\left.5 \mathrm{mg} \mathrm{L}^{-1}\right)$. A similar previous observation suggested that the distribution of streptomycin MICs was influenced 
Table 2 Activities of nine antibiotics against bacterial isolates harvested from stepwise increased STM exposures

\begin{tabular}{|c|c|c|c|c|c|c|c|}
\hline \multirow[t]{2}{*}{ Antibiotics } & \multirow{2}{*}{$\begin{array}{l}\text { Antibiotic range } \\
\left(\mu \mathrm{gL}^{-1}\right)\end{array}$} & \multicolumn{6}{|c|}{ Prevalence of antibiotic resistance $(\%)^{\mathbf{a}}$} \\
\hline & & $0 \mathrm{mg} \mathrm{L}^{-1}, \mathrm{STM}$ & $0.1 \mathrm{mg} \mathrm{L}^{-1}$, STM & $1 \mathrm{mg} \mathrm{L}^{-1}$, STM & $5 \mathrm{mg} \mathrm{L}^{-1}$, STM & $25 \mathrm{mg} \mathrm{L}^{-1}$, STM & $50 \mathrm{mg} \mathrm{L}^{-1}$, STM \\
\hline$A Z$ & $0.016-256$ & 0 & 38.4 & 38.4 & 30.8 & 23.0 & 23.0 \\
\hline TZ & $0.016-256$ & 7.7 & 23.0 & 38.4 & 23.0 & 15.4 & 15.4 \\
\hline EF & $0.002-32$ & 0 & 0 & 0 & 0 & 0 & 0 \\
\hline ETP & $0.064-1024$ & 0 & 0 & 7.7 & 7.7 & 7.7 & 7.7 \\
\hline SX & $0.002-32$ & 7.7 & 15.4 & 30.8 & 30.8 & 23.0 & 0 \\
\hline TC & $0.016-256$ & 0 & 23.0 & 30.8 & 30.8 & 30.8 & 15.4 \\
\hline TGC & $0.016-256$ & 0 & 0 & 0 & 0 & 0 & 0 \\
\hline TM & $0.016-256$ & 7.7 & 7.7 & 7.7 & 15.4 & 15.4 & 30.8 \\
\hline $\mathrm{Sm}$ & $1-1024$ & 15.4 & 53.8 & 69.2 & 69.2 & 53.8 & 53.8 \\
\hline
\end{tabular}

$A Z$ azithromycin, $T Z$ ceftazidime, EF enrofloxacin, ETP ertapenem, SX sulfamethoxazole, $T C$ tetracycline, TGC tigecycline, TM tobramycin, STM streptomycin a A total of 40 different bacterial strains (78 bacterial isolates, i.e. 13 isolates from each $\mathrm{Sm}$ stage) were used for MIC assay and the percentage of antibacterial resistance was calculated by the number of resistant strains among the total stains

and controlled by STM resistance genes in E. coli (Sunde and Norstrom 2005). Furthermore, parameters such as the presence of selected gene cassettes and integron genes located on low copy number plasmids and their placement in $3^{\prime}$-conserved segments might lead to variable STM MIC results (Bryan 1984; Levesque 1994). We believe that the above parameters might be controlled by the threshold concentrations of selected antibiotics, which mostly fall in minimal dose ranges.

At the same time, Aeromonas allosaccharophila and Aeromonas veronii were not resistant to STM $\left(<8 \mu \mathrm{g} \mathrm{mL}^{-1}\right)$ and did not contain any ARGs naturally $\left(0 \mathrm{mg} \mathrm{L}^{-1}\right)$. Subsequently, however, they became resistant to STM and ARGs were found (aacA4, strA, strB, aadA, $3^{\prime}-C S$, and $\operatorname{Int} 1$ ) in the corresponding STM exposures. This result indicates that STM resistance was promoted by stepwise increased STM concentrations, which might have occurred by the horizontal transfer of plasmids or transposons containing ARGs (Lekunberri et al. 2017; Van Overbeek et al. 2002; Rizzo et al. 2013; Czekalski et al. 2012). Interestingly, Bacillus anthracis was present and dominant in all six STM exposures $\left(0-50 \mathrm{mg} \mathrm{L}^{-1}\right)$, but the MIC results showed high sensitivity to STM $\left(<6 \mu \mathrm{g} \mathrm{mL}^{-1}\right)$ and they were not grown in the growth agar media with low added STM dose $\left(0.1 \mathrm{mg} \mathrm{L}^{-1}\right)$. Surprisingly, this bacterial strain exhibited $\operatorname{str} A, \operatorname{str} B, \operatorname{aad} A$, aacA4, Int1 and $3^{\prime}-C S$ as confirmed by conventional PCR. Bacillus anthracis is a spore-forming bacteria and the causative agent of anthrax disease. In general, spores of Bacillus sp. are dormant and resistant to unfavorable conditions such as extreme temperature, radiation, and antibiotics (Tetz et al. 2016; Severson et al. 2009; Nicholson et al. 2000). Previous findings revealed that bacterial spores can maintain their complete genome and antibiotic resistance genes might be involved in the horizontal transfer of ARGs to other bacterial species (Tetz and Tetz 2017; Barra-Carrasco et al. 2014). Furthermore, some ARGs are not expressed in the bacterial spores, but will be part of the resistome. In our study, we believed that spores might be produced under low STM exposure $\left(0.1 \mathrm{mg} \mathrm{L}^{-1}\right)$ and persist until the high STM exposure $\left(>25 \mathrm{mg} \mathrm{L}^{-1}\right.$ ). However, further studies are needed to determine, whether the spores of $B$. anthracis play an important role in delivering STM resistance.

Non-pathogenic environmental bacteria such as Lactococcus chungangensis, Lactococcus raffinolactis, Chryseobacterium lactis, Aeromonas allosaccharophila and Pseudoxanthomonas mexicana showed the prevalence of strA, strB, aacA4, IntI and 3'-CS genes in the various STM exposures $\left(0-50 \mathrm{mg} \mathrm{L}^{-1}\right)$ and subsequently obtained STM resistance (> $256 \mu \mathrm{g} \mathrm{mL} \mathrm{m}^{-1}$ ) in the corresponding STM exposures. These results reveal that long-term increasing doses of STM can lead to non-pathogenic bacteria becoming perfect reservoirs of ARGs, which they might transfer to another bacterium via gene transfer, resulting in an abundance of MDR bacteria in WWTPs (Rizzo et al. 2013; Balcazar et al. 2015; Wellington et al. 2013).

In this study, most of the STM resistant strains from the reactor treated with various doses of STM $\left(0-50 \mathrm{mg} \mathrm{L}^{-1}\right)$ consisted of a $3^{\prime}$ conserved segment $\left(3^{\prime}-C S\right)$ of the clinically important class 1 integron gene and class I integrase (Int1) gene (85-92.5\%). In addition, amino glycoside resistance genes aacA4, strA, strB and aadA (67.5-82.5\%) were also distributed in most STM resistant strains from all STM exposures. These amino glycoside genes and integron genes were notably observed under the lowest STM dose $\left(0.1 \mathrm{mg} \mathrm{L}^{-1}\right)$. Therefore, minimum doses of STM might strongly induce the gene cassette of amino glycoside resistance genes among the wastewater 


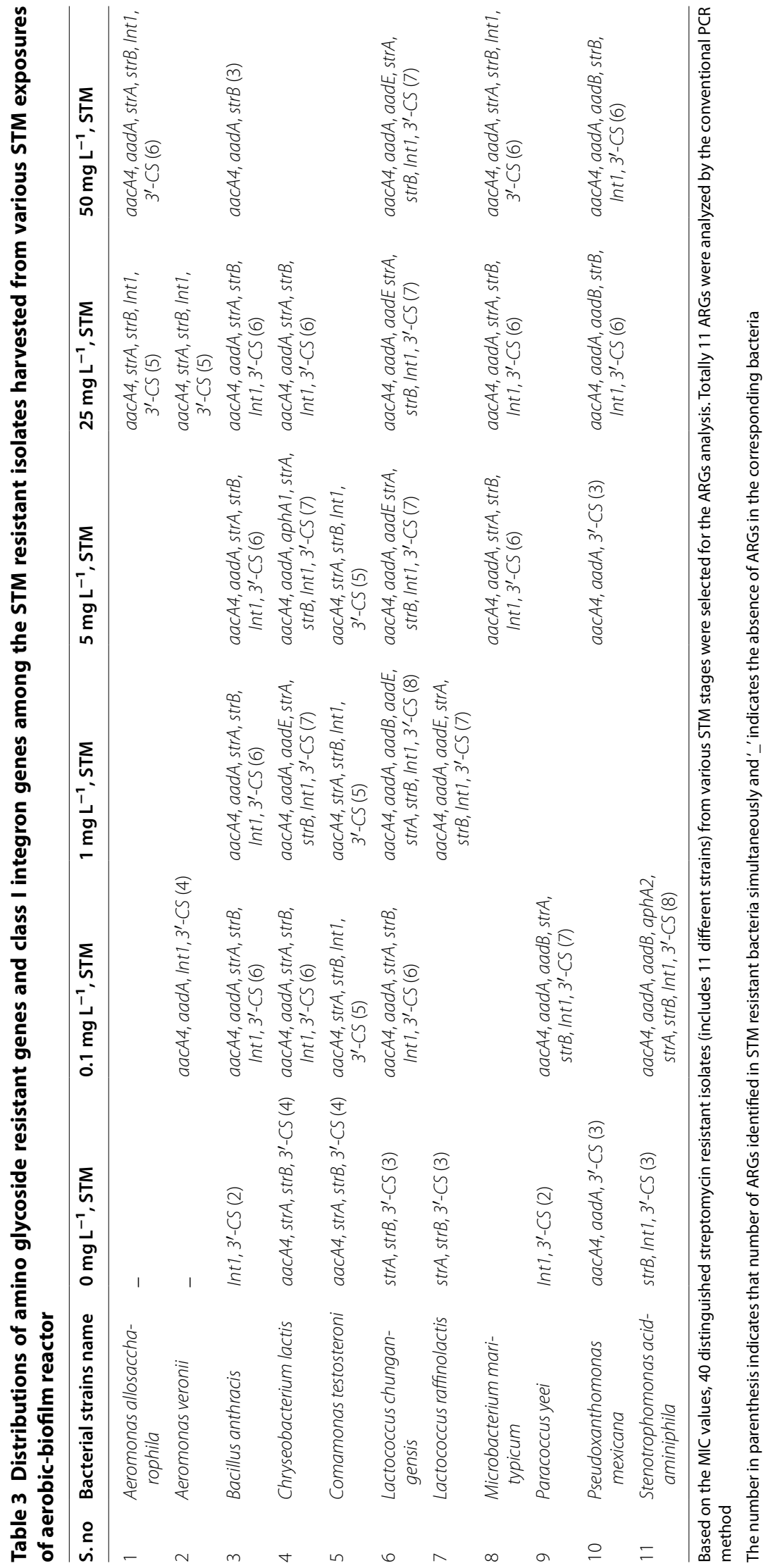


bacterial community related to the clinical class I integron and class I integrase enzymes. Subsequently, these class I integrons might induce the dissemination of STM resistance to other wastewater bacteria through horizontal mobile gene transfer, which might then be maintained even under higher doses of STM (Mokracka et al. 2012; Masarikova et al. 2016; Said et al. 2016; Stalder et al. 2013; Nemec et al. 2004).

We also observed high prevalence of a non-STM resistance gene aacA4 among the isolates harvested from the STM reactor exposure by involving stepwise increasing doses of STM $\left(0-50 \mathrm{mg} \mathrm{L}^{-1}\right)$. According to previous research, aacA4 is an amino glycoside gene that encodes the enzyme, amino glycoside $6^{\prime}-N$-acetyl transferase $\left(\mathrm{AAC}\left(6^{\prime}\right)-\mathrm{IbC}\right)$ and confers resistance to antibiotics such as tobramycin, gentamycin and kanamycin (Nemec et al. 2004; Sacha et al. 2012). In the present study, however a prevalence of the aacA4 gene was observed among $82.5 \%$ of STM isolates, equal to the prevalence of STM resistance genes $\operatorname{str} A$, strB, aadA and aadE (15-82.5\%). It is unclear, whether increased doses of STM modified the aacA4 gene to encode STM-modifying enzymes or if it accelerated an unknown STM resistance mechanism. Further research is required to clarify this as well as antibiotic risk assessment in WWTPs. In conclusion, our present work reveals that the wide bacterial diversity among the indigenous bacteria from WWTPs exposed to long-term stepwise increasing doses of STM could become an enhanced and stable reservoir for the development of STM resistance. Here we concluded that stepwise increasing doses of antibiotics will expose a number of unanswered questions related to antibiotic resistance among the wastewater bacterial community. We therefore suggest that the current new approach could apply and extended in future studies to better understand the risk assessment of WWTPs.

\section{Additional file}

Additional file 1. Tables and Figures.

\begin{abstract}
Abbreviations
STM: streptomycin; MDR: multi-drug resistance; MIC: minimum inhibitory concentration; WWTP: wastewater treatment plants; ARB: antibiotic resistant bacteria; ARGs: antibiotic resistance genes; PCR: polymerase chain reaction; HRT: hydraulic retention time; TSA: trypticase soya agar; CFUs: colony forming units; mM: milli molar; $\mu$ M: micro molar; RDP: Ribosomal Database Project; NCBI: National Center for Biotechnology Information; CLSI: Clinical and Laboratory Standards Institute; AZ: azithromycin; TZ: ceftazidime; EF: enrofloxacin; SX: sulfamethoxazole; TC: tetracycline; TM: tobramycin; TGC: tigecycline; ETP: ertapenem; MH: Mueller Hinton; 3'-CS: class I integron gene; Intl: class I integrase gene; $\mathrm{Mg} \mathrm{L}^{-1}$ : milligram per liter.
\end{abstract}

\section{Authors' contributions}

GS have done all the measurements and experiments and drafted the manuscript. MY and YZ supervised and provided an important intellectual content in the research design, coordination of the study and contributed in the drafting of the manuscript. ZT, HZ and JM analyzed the data and contributed to the statistical analysis. All authors read and approved the final manuscript.

\section{Author details}

${ }^{1}$ State Key Laboratory of Environmental Aquatic Chemistry, Research Center for Eco-Environmental Sciences, Chinese Academy of Sciences, Beijing 100085 China. ${ }^{2}$ University of Chinese Academy of Sciences, Beijing 100049, China.

\section{Acknowledgements}

We gratefully thank Chinese Academy of Sciences (CAS) and National Natural Scientific Foundation of China (NSFC) for their financial support.

\section{Competing interests}

The authors declare that they have no competing interests.

\section{Availability of data and materials}

All datasets supporting the conclusions of the manuscript were included in the article.

\section{Consent for publication}

Not applicable.

\section{Ethics approval and consent to participate}

Not applicable.

\section{Funding}

This study was supported by National Natural Scientific Foundation of China (No. 21437005) and Chinese Academy of Sciences (CAS) _-President's International Fellowship Initiative (PIFI) (No. 157077), People Republic of China.

\section{Publisher's Note}

Springer Nature remains neutral with regard to jurisdictional claims in published maps and institutional affiliations.

Received: 2 November 2017 Accepted: 15 January 2018

Published online: 25 January 2018

\section{References}

Andrews JM (2001) Determination of minimum inhibitory concentrations. J Antimicrob Chemother 48:5-10

Ashbolt NJ, Amézquita A, Backhaus T, Borriello P, Brandt KK, Collignon P, Coors A, Finley R, Gaze WH, Heberer T, Lawrence JR, Larsson DJ, McEwen SA, Ryan JJ, Schönfeld J, Silley P, Snape JR, Eede CVD, Topp E (2013) Human health risk assessment (HHRA) for environmental development and transfer of antibiotic resistance. Environ Health Perspect 121(9):993-1001

Aubertheau E, Stalder T, Mondamert L, Ploy MC, Dagot C, Labanowski J (2017) Impact of wastewater treatment plant discharge on the contamination of river biofilms by pharmaceuticals and antibiotic resistance. Sci Total Environ 579:1387-1398

Balcazar JL, Subirats J, Borrego CM (2015) The role of biofilms as environmental reservoirs of antibiotic resistance. Front Microbiol 6:1216

Barra-Carrasco J, Hernandez-Rocha C, Ibáñez P, Guzman-Duran AM, AlvarezLobos M, Paredes-Sabja D (2014) Spores of Clostridium difficile and its relevance in the persistence and transmission of infection. Rev chilena infectol 31(6):694-703

Bramucci M, Kane H, Chen M, Nagarajan V (2003) Bacterial diversity in an industrial wastewater bioreactor. Appl Microbiol Biotechnol 62(5-6):594-600

Bryan LE (1984) Amino glycoside resistance. In: Bryan LE (ed) Antimicrobial drug resistance. Academic Press, Orlando, pp 242-273

CLSI (2016) Mehtods for antimicrobial dilution and disk susceptibility testing of infrequently isolated or fastidious bacteria. Wayne, CLSI guideline M45, pp 7-46

Czekalski N, Berthold T, Caucci S, Egli A, Burgmann H (2012) Increased levels of multi resistant bacteria and resistance genes after wastewater treatment and their dissemination into Lake Geneva, Switzerland. Front Microbiol. 106:3 
De Leon Door AP, Romo Chacon A, Acosta Muniz C (2013) Detection of streptomycin resistance in Erwinia amylovora strains isolated from apple orchards in Chihuahua, Mexico. Eur J plant Pathol 137(2):223-229

Deng Y, Zhang Y, Gao Y, Li D, Liu R, Liu M, Zhang H, Hu B, Yu T, Yang M (2012) Microbial community compositional analysis for series reactors treating high level antibiotic wastewater. Environ Sci Technol 46:795-801

Felsenstein J (1985) Confidence limits on phylogenies: an approach using the bootstrap. Evolution 39:783-791

Gallert C, Fund K, Winter J (2005) Antibiotic resistance of bacteria in raw and biologically treated sewage and in groundwater below leaking sewers. Appl Microbiol Biotechnol 69:106-112

Guo J, Li J, Chen H, Bond PL, Yuan Z (2017) Metagenomic analysis reveals wastewater treatment plants as hotspots of antibiotic resistance genes and mobile genetic elements. Water Res 123:468-478

Jutkina J, Rutgersson C, Flach CF, Larsson DGJ (2016) An assay for determining minimal concentrations of antibiotics that drive horizontal transfer of resistance. Sci Total Environ 548-549:131-138

Kim S, Yun Z, Ha UH, Lee S, Park H, Kwon EE, Cho Y, S Choung, Oh J, Carl AM, Chandran K (2014) Transfer of antibiotic resistance plasmids in pure and activated sludge cultures in the presence of environmentally representative micro-contaminant concentrations. Sci Total Environ 468-469:813-820

Larkin MA, Blackshields G, Brown NP, Chenna R, McGettigan PA, McWilliam H, Valentin F, Wallace IM, Wilm A, Lopez R, Thompson JD, Gibson TJ, Higgins DG (2007) Clustal W and Clustal X version 2.0. Bioinformatics 23:2947-2948

Lekunberri I, Villagrasa M, Balcázar JL, Borreg CM (2017) Contribution of bacteriophage and plasmid DNA to the mobilization of antibiotic resistance genes in a river receiving treated wastewater discharges. Sci Total Environ 601-602:206-209

Levesque C, Brassard S, Lapointe J, Roy PH (1994) Diversity and relative strength of tandem promoters for the antibiotic resistance genes of several integrons. Gene 142:49-54

Levy SB, Fitzgerald GB, Macone AB (1976) Changes in intestinal flora of farm personnel after introduction of a tetracycline-supplemented feed on a farm. NEngl J Med 295:583-588

Li D, Yang M, Hu J, Zhang J, Liu Z, Gu X, Zhang Y, Wang Z (2009) Antibioticresistance profile in environmental bacteria isolated from penicillin production wastewater treatment plant and the receiving river. Environ Microbiol 11(6):1506-1517

Li D, Yu T, Zhang Y, Yang M, Li Z, Liu M, Qi R (2010) Antibiotic resistance characteristics of environmental bacteria from an oxytetracycline production wastewater treatment plant and the receiving river. Appl Environ Microbiol 76(11):3444-3451

Li D, Qi R, Yang M, Zhang Y, Yu T (2011) Bacterial community characteristics under long-term antibiotic selection pressures. Water Res 45:6063-6073

Liu M, Ding R, Zhang Y, Gao Y, Tian Z, Zhang T, Yang M (2014) Abundance and distribution of macrolide-lincosamide-streptogramin resistance genes in an anaerobic-aerobic system treating spiramycin production wastewater. Water Res 63:33-41

Lundstrom SV, Östman M, Bengtsson-Palme J, Rutgersson C, Thoudal M, Sircar T, Blanck P, Eriksson KM, Tysklind M, Flach C, Larsson DGJ (2016) Minimal selective concentrations of tetracycline in complex aquatic bacterial biofilms. Sci Total Environ 553:587-595

Mao M, Yu S, Rysz M, Luo Y, Yang F, Li F, Hou J, Mu Q, Alvarez PJJ (2015) Prevalence and proliferation of antibiotic resistance genes in two municipal wastewater treatment plants. Water Res 85:458-466

Masarikova M, Manga I, Cizek A, Dolejska M, Oravcova V, Myskova P, Karpiskova R, Litera I (2016) Salmonella enteric resistant to antimicrobials in wastewater effluents and black-headed gulls in the Czech Republic, 2012. Sci Total Environ 542:102-107

Michael I, Rizzo L, McArdell CS, Manaia CM, Merlin C, SchwartzT, Dagot C, Fatta-Kassinos D (2013) Urban wastewater treatment plants as hotspots for the release of antibiotics in the environment: a review. Water Res 447:345-360

Mokracka J, Koczura R, Kaznowski A (2012) Multi resistant Enterobacteriaceae with class 1 and class 2 integrons in a municipal wastewater treatment plant. Water Res 46(10):3353-3363
Nemec A, Dolzani L, Brisse S, Van den Broek P, Dijkshoorn L (2004) Diversity of aminoglycoside-resistance genes and their association with class 1 integrons among strains of pan-European Acinetobacter baumannii clones. J Med Microbiol 53:1233-1240

Nicholson WL, Munakata N, Horneck G, Melosh HG, Setlow P (2000) Resistance of bacillus endospores to extreme terrestrial and extraterrestrial environments. Microbiol Molecul Biol Rev 64(3):548-572

Novo A, Manaia CM (2010) Factors influencing antibiotic resistance burden in municipal wastewater treatment plants. Appl Microbiol Biotechnol 87:1157-2116

Popowska P, Rzeczycka M, Miernik A, Krawczyk-Balska A, Walsh F, Duffy B (2012) Influence of soil use on prevalence of tetracycline, streptomycin, and erythromycin resistance and associated resistance genes. Antimicrob Agents Chemother 56(3):1434-1443

Pruden A, Larsson DGJ, Amézquita A, Collignon P, Brandt KK, Graham DW, Lazorchak JM, Suzuki S, Silley P, Snape R, Topp E, Zhang T, Zhu YG (2013) Management options for reducing the release of antibiotics and antibiotic resistance genes to the environment. Environ Health Perspect 121(8):878-885

Rizzo L, Manaia C, Merlin C, Schwartz T, Dagot C, Ploy MC, Michael I, FattaKassinos D (2013) Urban wastewater treatment plants as hotspots for antibiotic resistant bacteria and genes spread into the environment: a review. Sci Total Environ 447:345-360

Rodriquez-Mozaz S, Chamorro S, Marti E, Huerta B, Gros M, Sanchez-Melsio A, Borrego CM, Barcelo B, Balcazar JL (2015) Occurrence of antibiotics and antibiotic resistance genes in hospital and urban wastewaters and their impact on the receiving river. Water Res 69:234-242

Sacha P, Jaworowska J, Ojdana D, Wieczorek P, Czaban S, Tryniszewska E (2012) Occurrence of the aacA4 gene among multidrug resistant strains of Pseudomonas aeruginosa isolated from bronchial secretions obtained from the Intensive therapy unit at university hospital in Bialystok, Poland. Folia Histochem Cytobiol 50(2):322-324

Said BN, Jouini A, Alonso CA, Klibi N, Dziri R, Boudabous A, Slama KD, Torres C (2016) Characteristics of extended-spectrum $\beta$-lactamase (ESBL)- and PAmpC beta-lactamase-producing Enterobacteriaceae of water samples in Tunisia. Sci Total Environ 550:1103-1109

Severson KM, Mallozzi M, Bozue J, Welkos SL, Cote CK, Knight KL, Driks A (2009) Roles of the Bacillus anthracis spore protein ExsK in exosporium maturation and germination. J Bacteriol 191(24):7587-7596

Stalder T, Barraud O, Jove T, Casellas M, Gaschet M, Dagot C, CecilePloy M (2013) Quantitative and qualitative impact of hospital effluent on dissemination of the integron pool. ISME J 8(4):768-777

Sunde M, Norstrom M (2005) The genetic background for streptomycin resistance in Escherichia coli influences the distribution of MICs. J Antimicrob Chemother 56:87-90

Sundin G (2002) Distinct recent lineages of the strA-strB Streptomycinresistance genes in clinical and environmental bacteria. Curr Microbiol 45(1):63-69

Sundin GW, Monks DE, Bender CL (1995) Distribution of the streptomycin resistance transposon Tn5393 among phylloplane and soil bacteria from managed agricultural habitats. Can J Microbiol 41(9):792-799

Tacão M, Moura A, Correia A, Henriques I (2014) Co-resistance to different classes of antibiotics among ESBL-producers from aquatic systems. Water Res 1:100-107

Tamura K, Stecher G, Peterson D, Filipski A, Kumar S (2013) MEGA6: molecular evolutionary genetics analysis version 6.0. Mol Biol Evol 30:2725-2729

Tetz G, Tetz V (2017) Introducing the sporobiota and sporobiome. Gut Pathog 9:38

Tetz G, Tetz V, Vecherkovskaya M (2016) Genomic characterization and assessment of the virulence and antibiotic resistance of the novel species Paenibacillus sp. strain VT-400, a potentially pathogenic bacterium in the oral cavity of patients with hematological malignancies. Gut Pathog. 8:6

Um MM, Barraud O, Kerouredan M, Gaschet M, Stalder T, Oswald E, Dagot C, Ploy MC, Brugere H, Bibbal B (2016) Comparison of the incidence of pathogenic and antibiotic-resistant Escherichia coli strains in adult cattle and veal calf slaughterhouse effluents highlighted different risks for public health. Water Res 88:30-38

Van Overbeek LS, Wellington EM, Egan S, Smalla K, Heuer H, Collard JM, Guillaume G, Karagouni AD, Nikolakopoulou TL, Van Elsas JD (2002) 
Prevalence of streptomycin-resistance genes in bacterial populations in European habitats. FEMS Microbiol Ecol 42(2):277-288

Wellington EM, Boxall AB, Cross P, Feil EJ, Gaze WH, Hawkey PM, Johnson-Rollings AS, Jones DL, Lee NM, Otten W, Thomas CM, Williams AP (2013) The role of the natural environment in the emergence of antibiotic resistance in Gram-negative bacteria. Lancet Infect Dis 13(2):155-165
Wong PHP, Krosigk MV, Roscoe DL, Lau TTY, Yousefi M, Bowie WR (2014) Antimicrobial co-resistance patterns of Gram-negative Bacilli isolated from bloodstream infections: a longitudinal epidemiological study from 2002-2011. BMC Infect Dis 14:393

\section{Submit your manuscript to a SpringerOpen ${ }^{\circ}$ journal and benefit from:}

- Convenient online submission

- Rigorous peer review

- Open access: articles freely available online

- High visibility within the field

- Retaining the copyright to your article

Submit your next manuscript at $\boldsymbol{\nabla}$ springeropen.com 